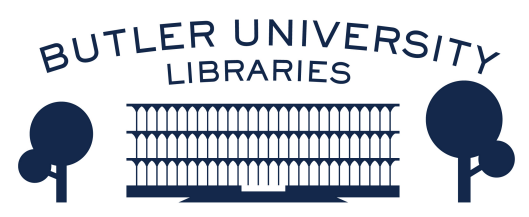

Journal of Hindu-Christian Studies

Volume 18

Article 20

January 2005

\title{
Book Review: "Converting Women: Gender and Protestant Christianity in Colonial South India"
}

Leslie C. Orr

Follow this and additional works at: https://digitalcommons.butler.edu/jhcs

Part of the Religion Commons

\section{Recommended Citation}

Orr, Leslie C. (2005) "Book Review: "Converting Women: Gender and Protestant Christianity in Colonial South India"," Journal of Hindu-Christian Studies: Vol. 18, Article 20.

Available at: https://doi.org/10.7825/2164-6279.1353

The Journal of Hindu-Christian Studies is a publication of the Society for Hindu-Christian Studies. The digital version is made available by Digital Commons @ Butler University. For questions about the Journal or the Society, please contact cbauman@butler.edu. For more information about Digital Commons @ Butler University, please contact digitalscholarship@butler.edu. 
noting that almost all female gurus are not in traditional lineages that wield orthodox power but are "stand-alone" figures who tap into universality and the philosophical oneness of Vedanta.

My one small reservation about this splendid collection of essays is the uneven attention by the authors to the darker sides of the individuals and organizations they describe. For gurus like Sita Devi, Gauri $\mathrm{Ma}$, or Anandamayi Ma, perhaps there are no sources for their more human sides, particularly since two of them were not supposed to be human. I wonder however about the rather idealized picture of Shree Ma of Kamakkhya, she who stands with the dispossessed other, in Biernacki's essay. In the same vein, it takes a small army of devoted disciples to manage and facilitate Ammachi's 1,800 hugs a day; as a guru her innovative maternal ministry may indeed be healing for the recipients, but one also hears stories of the near slavery of those close to her, in terms of work expectations. Again, Pechilisí n. 28 p. 239 on accusations against the SYDA Foundation is so carefully worded as to tell us practically nothing. It is of course an extremely sensitive task to write on current gurus, especially if one has received kindness from them and their followers. Nevertheless, a discussion about what kinds of worries have exercised the disciples and ex-disciples of female gurus could be a fruitful, additional lens through which to understand the group as a whole. In this regard, I find Cornille's essay on Mother Meera to be exemplary. She mentions, up front, discomfitting facts about her subject, and yet her presentation of Mother Meera as a woman who awakens insights in her disciples also makes one take this guru seriously.

These concerns aside, The Graceful Guru is a lovely volume that teaches us a lot about the category of women gurus through interesting descriptions of some famous examples. The volume layout is beautiful, too, with an initial introduction to each of the authors, references and books for further reading collected after each essay, and a final list of websites. If only Oxford had agreed to invest in some photographs!

Rachel Fell McDermott Barnard College

\section{Converting Women: Gender and Protestant Christianity in Colonial South India. Eliza F. Kent. New York: Oxford University Press, 2004, xiv +315 pp.}

\begin{abstract}
ELIZA Kent's study of conversion in the Tamil country of the 19th and early 20th centuries focusses on women -- Western women who were Protestant missionaries, Indian women who converted to Christianity, and issues relating to women's conduct and capacities that were brought into play by these women's propagation of and responses to Christianity. Drawing on an array of Tamil sources, as well as the records and publications in English of missionaries, colonial administrators, and Indian Christians, Kent's effort is to provide an account of the processes and meanings of
\end{abstract}

conversion in terms of the theological, social and political context of these earlier times (as opposed to those of post-Independence India), and an account that reflects the motives and experiences of Indian converts. Given that the Indian converts whose perspectives Kent seeks to recover are not only women, but also frequently low-caste or untouchable, the historiographical challenges are considerable; nonetheless, the endeavour results in a distinctive and extremely valuable contribution.

This book's central thesis is that conversion to Christianity was not the 
function of the imposition from outside of foreign beliefs and practices, but a dialogical process involving the agency of the convert and a series of complex negotiations about the impact of the new religious identity on Indian lives. With sympathy for the sincerity and authenticity of the motives of both missionary and convert, and for the intense engagement with encounter and transformation that brought the two sides together, Kent draws attention to the lack of congruence between their understandings of the significance of the adoption of Christian values and behaviours by Indians. The concept of female respectability provides a wonderful example of the ways in which Western missionaries and Indian Christians invested a model for women's comportment with divergent meanings: on the one hand, as representing (and inculcating) the Christian virtues of modesty, chastity, and self-discipline, and on the other, as marking the convert's rising status with reference to Indian society's norms for the dress, movement outside the home, and sexual behaviour of women positioned variously within the hierarchy of caste. The fact that the sexual conduct of Western female missionaries, like other white women in colonial India, was subject to surveillance as rigorous as that endured by high-caste Hindu women only adds to the complexities and ironies of the situation. I find convincing Kent's suggestion that the acceptance by low-caste Indian Christian women of a parallel regulatory framework, although it curtailed their activities in a number of ways, was useful as an expression of resistance to the threat of sexual exploitation by upper-caste men.

Not only does this book provide a rich portrait of the diverse and distinct apprehensions of what conversion meant to missionaries and to Indian converts, but each of these two groups is represented as encompassing great variety. We learn that Protestant Christian groups had very different views about the nature of conversion and salvation, and about the aims and methods of their foreign missions. We come to appreciate the impact of female missionaries in South India, and that their concerns, experiences, and fields of activity were often quite separate from those of their male counterparts. With reference to the groups of low-caste Indians among whom the South Indian missionaries worked, Kent does an admirable job of deconstructing the images projected by colonial ethnographers and administrators, and by the missionaries themselves. Her presentation not only counters colonial stereotypes of untouchables as depraved and/or as abject victims, but introduces us to the variety of conditions and ways of life with which members of these communities were involved, as well as the historical dynamics of the colonial period which dramatically altered their opportunities and their vulnerabilities. The diverse types of missionaries and of Christian converts -- and insight into the convictions and motivations that may have belonged to members of the groups they belonged to -- are brought to life by Kent's portraits. She employs a range of different kinds of sources to provide details of the activities and attitudes of Amy Carmichael and Eva Swift in her very rich chapter on "Women's Missionary Societies," and of the conceptions of Christianity and domesticity that were salient for the Satthianadhan family and for the Reverend A.N. Sattampillai. She makes skillful use of the fragmentary material that sheds light on the functions and character of the Indian "Bible women," and revisits the missionary archive to recover other glimpses of the experience of Indian Christians. Although these people may have become Christians as the result of "mass conversions," and despite the author's statement (p. 7) that her focus is "on the public, social aspect of conversion," there is a great deal in this book that treats the individual and the interior.

Kent argues that for Indian women and low-caste men, conversion to Christianity was a means of reformulating one's social identity, carrying with it an implicit critique of the dominant Hindu society's patriarchal and hierarchical tendencies. She does not claim that Christianity was the only worldview that 
presented such alternatives, and points toward the possibility that other religious movements such as the cult of Murukan were "a focus of low-caste restlessness in nineteenth-century South India" (p. 248). Although there seems to be little research on such movements, I would have liked to see some further discussion of the parallels with conversion to Christianity. I am also curious about the suggestion in Kent's conclusion that it has not only been in the colonial period that "gaps and fissures" (p. 3) have appeared in Indian society which have provided the impetus and opportunity for social and religious self-transformation. What comparisons can be made between the conditions that prevailed in the colonial period and those of the times of the Buddha or the bhakti saints? Or is it the content of the message, rather than the context in which it is encountered, that is most responsible for its appeal?

It is likely that a consideration of such far-ranging questions would have led our author too far afield; the fact that they spring to mind at all is an indication of the quality and value of this book. For while Kent's graceful prose and balanced presentation please the reader, the account she provides of the actions and experiences of her subjects is provocative. Part of the story is about collaboration, resourcefulness, and self-transformation, but Kent is right to remind us that these religious interactions also involved conflict, rupture, and uneasy compromise. Her focus on women in this arena, and on both Western and Indian women, gives her the opportunity to teach us much that is new about the processes and tensions of conversion and of the colonial encounter. And the sensitivity and imagination she brings to her portrayal of the people enmeshed with one another in this context makes their struggles and achievements poignant and compelling.

Leslie C. Orr Concordia University

\section{Briefly Noted}

Asian Christian Theologies: A Research Guide to Authors, Movements, Sources. Volume 1: Asia Region 7th-20th centuries; South Asia; Austral Asia. Edited by John C. England; Jose Kuttianimattathil, S.D.B.; John Mansford Prior, S.V.D.; Lily A. Quintos, R.C.; David Suh Kwang-sun; Janice Wickeri. Maryknoll, New York: Orbis/Delhi: ISPCK/Quezon City: Claretian Publishers, 2002, xlv +679 pp.

THE compilers, writers and editors of this fine three volume encyclopedia have taken on the formidable task of mapping historically, geographically, thematically and biographically the myriad expressions of Asian Christian theology. Of the three volumes, the first will be of greatest usefulness to those interested in the interaction of Hinduism and Christianity, since it covers South Asia and India. The general theme of Volume 2 (2003), by contrast, is Southeast Asia, that of Volume 3 (2004) Northeast Asia.

The project of compilation, which began in 1998, is ambitious; the editors' expressed intent is to provide the "first wide-ranging attempt to chart the vast materials of Asian Christian theologies," (p. xlv) to make available the key sources and tools in English for the study of Catholic, Protestant and Orthodox Asian theology over the centuries. The focus throughout is on the understanding of Christian faith as expressed in theologies grounded in local contexts that draw on indigenous culture and religion. Accordingly, purely western theologies transplanted in Asia are of lesser interest. Special attention is also given to the voices of women in their "aspirations, faith and struggles against oppression" (p. 